\title{
Climate influences on upper Limpopo River flow
}

\author{
Mark R Jury, ${ }^{1,2 *}$ \\ 'Physics Dept, University of Puerto Rico Mayagüez, PR 00681, Puerto Rico \\ 2University of Zululand, PB X1001, KwaDlangezwa 3886, South Africa
}

\begin{abstract}
This study demonstrates how the regional climate affects river flow in the upper Limpopo Valley of southern Africa (21-24.5S, 26-30E). The catchment basin receives inflow from the Crocodile, Marico, Mahalapse and Lotsane Rivers, and lies on the eastern fringe of the Kalahari plateau, known for water-deficit conditions. Different ways to represent the surface water balance are compared. The annual cycle of gains from precipitation $(P)$ spikes upward in late summer (Jan-Mar), while losses from evaporation have a broad peak in early summer (Oct-Dec). Different formulations of the surface water balance yield a range of values from -0.21 to $-1.69 \mathrm{~mm} / \mathrm{day}$, depending on how evaporation is quantified. An analysis of global climatic influences on the Limpopo River found that high flow coincides with Pacific La Niña, low pressure over the central Atlantic and local upper easterly winds that draw tropical moisture from the Mozambique Channel. There is little trend in Limpopo River flow during the study period 1959-2014; however, CMIP5 model projections exhibit a downtrend in the surface water balance. A new insight is that evaporation losses are well represented by sensible heat flux in semi-arid environments.
\end{abstract}

Keywords: Limpopo Valley, hydro-meteorology, surface water deficit

\section{INTRODUCTION}

The Limpopo River meanders across the arid Kalahari plateau between South Africa, Botswana and Zimbabwe, before descending to the humid lowlands of Mozambique. The upper catchment and its tributaries (Marico-Crocodile-MahalapseLotsane) constitute a broad valley extending from 21-24.5 S and 26-30 E, with a gentle slope initially northward then eastward toward the Indian Ocean, from $895 \mathrm{~m}$ at $26 \mathrm{E}$ to $423 \mathrm{~m}$ at $30 \mathrm{E}$. The area has been occupied by nomadic farmers over past millenia and there is a history of drought impacts on vegetation (Ekblom et al., 2012). Monthly river flow records reveal peak discharge of $\sim 1000 \mathrm{~m}^{3} / \mathrm{s}$ that declines to near zero in winter (Jul-Sep) and remains $<10 \mathrm{~m}^{3} / \mathrm{s}$ in multi-annual drought. The hydrology is regulated by barrages and reservoirs which exert a steady demand on water resources (UNDP, 2007), particularly within South Africa. Total run-off is about $500 \mathrm{M} \mathrm{m}^{3} / \mathrm{yr}$, of which the Crocodile River contributes about half (LBPTC, 2010).

The upper Limpopo Valley has a crop area $>1 \mathrm{M}$ ha that is mostly rainfed and a population of $\sim 5 \mathrm{M}$. The climate is subtropical dry savanna, with the following mean annual values: temperature $22^{\circ} \mathrm{C}$, wind speed $4 \mathrm{~m} / \mathrm{s}$, rainfall $\sim 350 \mathrm{~mm}$, potential evaporation $>1200 \mathrm{~mm}$ and soil moisture $\sim 21 \%$. Most rain falls between November and March, concentrated in $\sim 7$ rain days per month. Seasonal rainfall fluctuates from year to year (Tyson et al., 2002; Venter et al., 2003; Tadross et al., 2005): the coefficient of variation is 0.35 , a constraint to crop production. Climate change research using CMIP3 model projections suggest a decline in summer run-off of 15\% (Zhu and Ringler, 2010).

The objective of this paper is to characterize the surface water budget of the upper Limpopo River valley using direct measurements and model estimates, to analyse seasonal and multi-annual variability, and to demonstrate how the largescale climate influences regional hydrological conditions.

\footnotetext{
* To whom all correspondence should be addressed.

e-mail: mark.jury@upr.edu

Received: 24 November 2014; accepted in revised form 17 November 2015
}

\section{DATA AND METHODS}

Limpopo River monthly peak flow data were obtained via the South African Department of Water and Sanitation's hydrology service website for the gauge at Groblersbrug (23S, 28E, cf. Fig. 1a) in the period 1959-2014. Pan evaporation measurements are obtained from Mokolo (917 m), Glen Alpine (822 m) and Nzhelele (628 m) (cf. Fig. 1b), and averaged together for comparison with model estimates. Supplementing the in-situ hydrological record are area-averaged (21-24.5S, 26-30E) latent heat flux (LHF) and sensible heat flux (SHF) from the Global Land Data Assimilation System (GLDAS, Rodell et al 2004) NOAH hydrological model. Area-averaged LHF/SHF and climatic fields are derived from ECMWF and MERRA reanalysis models (Dee et al., 2011; Rienecker et al., 2011). Monthly gauge rainfall observations interpolated to $50 \mathrm{~km}$ grid are obtained from GPCC (Schneider et al., 2013) and the CRU potential evapo-transpiration (PET) is utilized, based on the Penman-Monteith calculation (Hargreaves and Samani, 1982; Harris et al., 2013). Additional datasets include MODIS satellite infrared surface temperatures and vegetation colour fraction at $1 \mathrm{~km}$ resolution (Huete et al., 2002), and naturally cover a period more recent than the in-situ measurements.

The temporal record of river flow was filtered to remove cycles $<18$ months and wavelet spectral energy was calculated to search for significant oscillations. Regional climate influences on the upper Limpopo water balance were studied by cross-correlation (cf. Glad, 2010). With 65 degrees of freedom, $90 \%$ confidence is reached with $r>|0.20|$. To focus on the less manipulated peak summer flow, Jan-Apr discharge was crosscorrelated with Dec-Mar reanalysis fields of surface temperature, air pressure and upper zonal wind (cf. Potter et al., 2004). At the climate change time scale, CMIP5 model simulations of Limpopo annual precipitation minus SHF were analysed using the rcp6 scenario. The models and scenarios are described in Taylor et al. (2012). CMIP5 outputs consistent with observed values were identified (cf. Jury, 2012) and projections were evaluated for trends (cf. Kumambala and Ervine, 2010). Case studies were analysed for a drought (Dec-Mar 1992) and flood 
(1-13 Mar 2014), to understand the climate and weather influences. The flood analysis makes use of daily river flow and satellite rainfall (Joyce et al., 2004), HYSPLIT airflow trajectories, regional sea surface temperature and $200 \mathrm{hPa}$ geopotential height anomalies.

\section{RESULTS}

\section{Limpopo hydro-climate}

Figure la-c introduces the Limpopo River basin topography and tributaries, and the mean patterns of satellite vegetation fraction and day-time surface temperatures. It is evident that the upper Limpopo Valley is broad and drains eastward from the Kalahari Desert. It borders 3 countries: Botswana, South Africa and Zimbabwe. Water abstraction for urban consumption (e.g. Gaborone, Gauteng) and agricultural production has been relatively steady (UNDP, 2007), so peak river flow tends to follow climatic anomalies. The Limpopo areaaveraged mean vegetation fraction is $36 \%$ and the day-time surface temperature is $38^{\circ} \mathrm{C}$. The mean soil moisture fraction is $\sim 21 \%$, depending on data source, indicating water deficit conditions.

The temporal record of monthly peak flow at the Groblersbrug gauge is given in Fig. 2a. It shows a seasonal spike each year that rises in the late 1970s, diminishes in the 1980s to early 1990s and rises again in the 2000s. There is a no significant overall trend. A good portion of the flow derives from the Crocodile River (LBPTC, 2010) that is abstracted within South Africa and joins the Limpopo below Gaborone.

Oscilations in the Limpopo River flow are revealed in the wavelet spectral energy of filtered river flow anomalies (Fig. 2b). There is significant cycling from $2-5$ years and $10-11$ years. The faster cycling obtains higher amplitude during the wet spells of the 1965-1980 and 1996-2000, while the slower cycling is most pronounced in the dry 1980s.

\section{Annual cycle}

The annual cycle of precipitation $(P)$ minus evaporation $(E)$ is studied using LHF or SHF (respectively, $P-E_{L}, P-E_{S}$ where: $L=$ latent, $S=$ sensible). Mean annual values $(\mathrm{mm} /$ day) are: $P=1.11, \mathrm{LHF}=1.32, \mathrm{SHF}=2.80, P-E=-0.21 \mathrm{using} \mathrm{LHF}$ or -1.69 using SHF. The $P-E_{L}$ reveals neutral conditions and a flat seasonal shape (Fig. 3a) with a small peak in Nov-Dec and weak deficit in Apr-May. The $P-E_{S}$ resolves a water deficit $<-3 \mathrm{~mm} /$ day in Sep-Oct when river flow ceases. Peak river flow $\left(100 \mathrm{~m}^{3} / \mathrm{s}\right)$ in the annual cycle occurs in Feb-Mar, following a month behind the peak of $P-E_{s}$.

In Fig. $3 b$ the mean annual cycle of model estimated latent and sensible heat flux is compared with PET and vegetation fraction. The SHF is below PET but exhibits a similar shape, rising in Sep-Nov and dipping in May-Jul when frost occurs in the upper Limpopo Valley. In contrast, LHF peaks in Jan-Mar in conjunction with vegetation fraction. The LHF is far below SHF in the spring season (Sep-Nov). Scatterplot comparisons between monthly pan evaporation averaged at 3 stations (cf. Fig. 1b) and model-estimated heat fluxes are given in Fig. 3c,d. The LHF $r^{2}$ is low (0.15) and exhibits a weak relationship with measured pan evaporation ( $15 \%$ of variance). The sensible heat flux, parameterized as wind speed times surface minus air temperature, fits the pan evaporation very well ( $69 \%$ of variance).
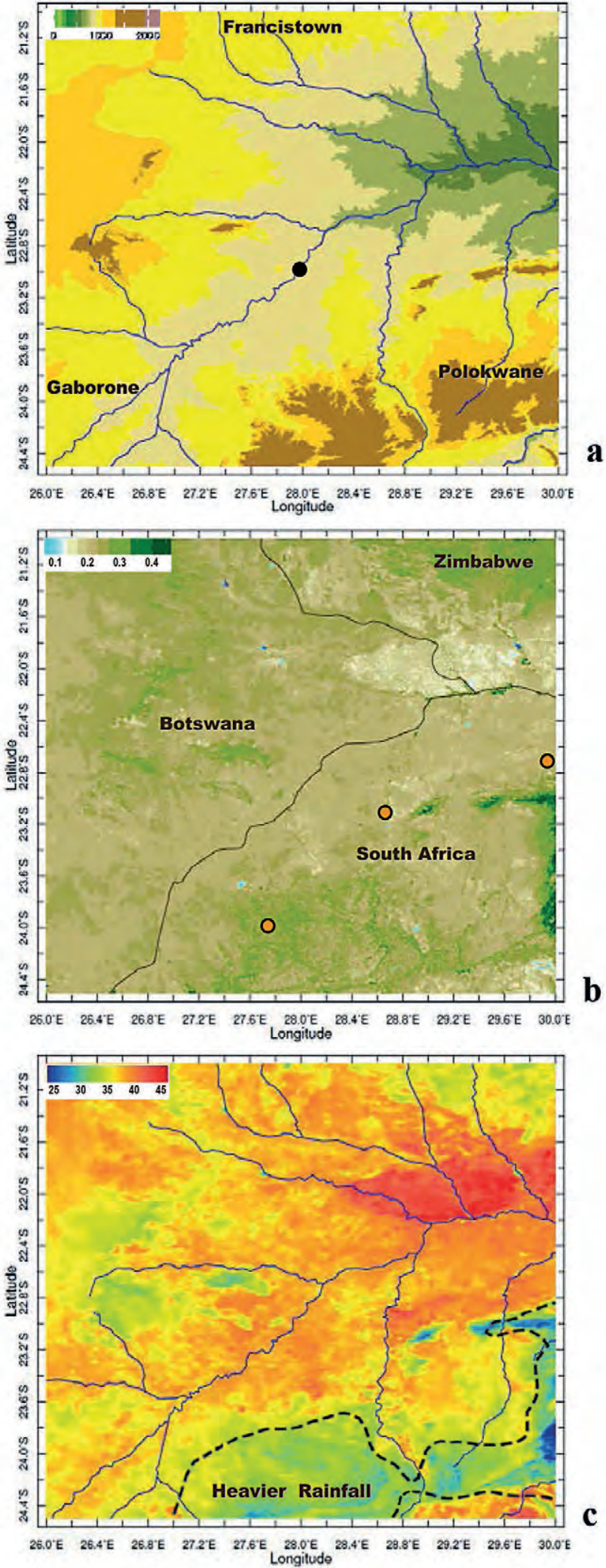

Figure 1

Location maps for upper Limpopo River valley: (a) elevation, (b) mean vegetation fraction, (c) mean day-time land surface temperature.

Black dot in (a) is flow gauge, rivers are shown in $(a, c),(b)$ has national boundaries and pan evaporation stations (orange dots). Dashed area in (c) has heavier summer rainfall. 

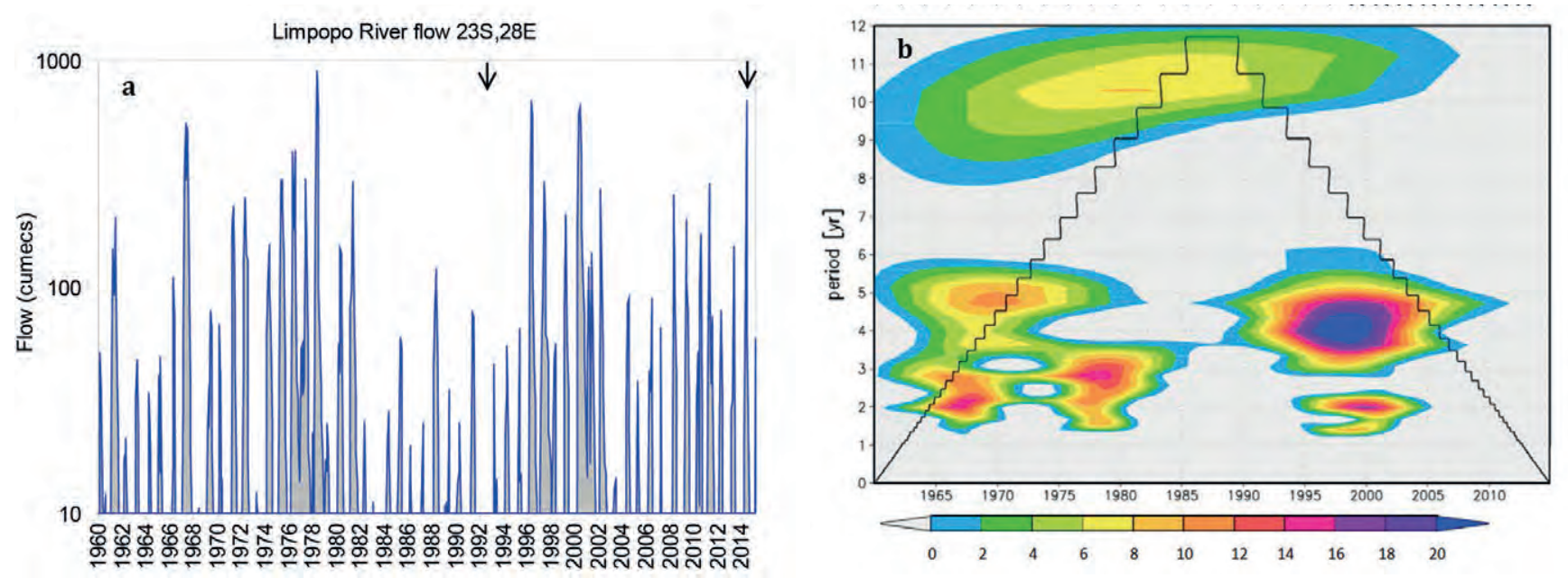

Figure 2

(a) Temporal record of peak monthly Limpopo River flow at the Groblersbrug gauge, with log scale starting at $10 \mathrm{~m}^{3} / \mathrm{s}$. (b) Wavelet spectral analysis of filtered river flow, with power $<90 \%$ confidence masked and cone of validity (stepped line). Arrows in (a) point to case studies.
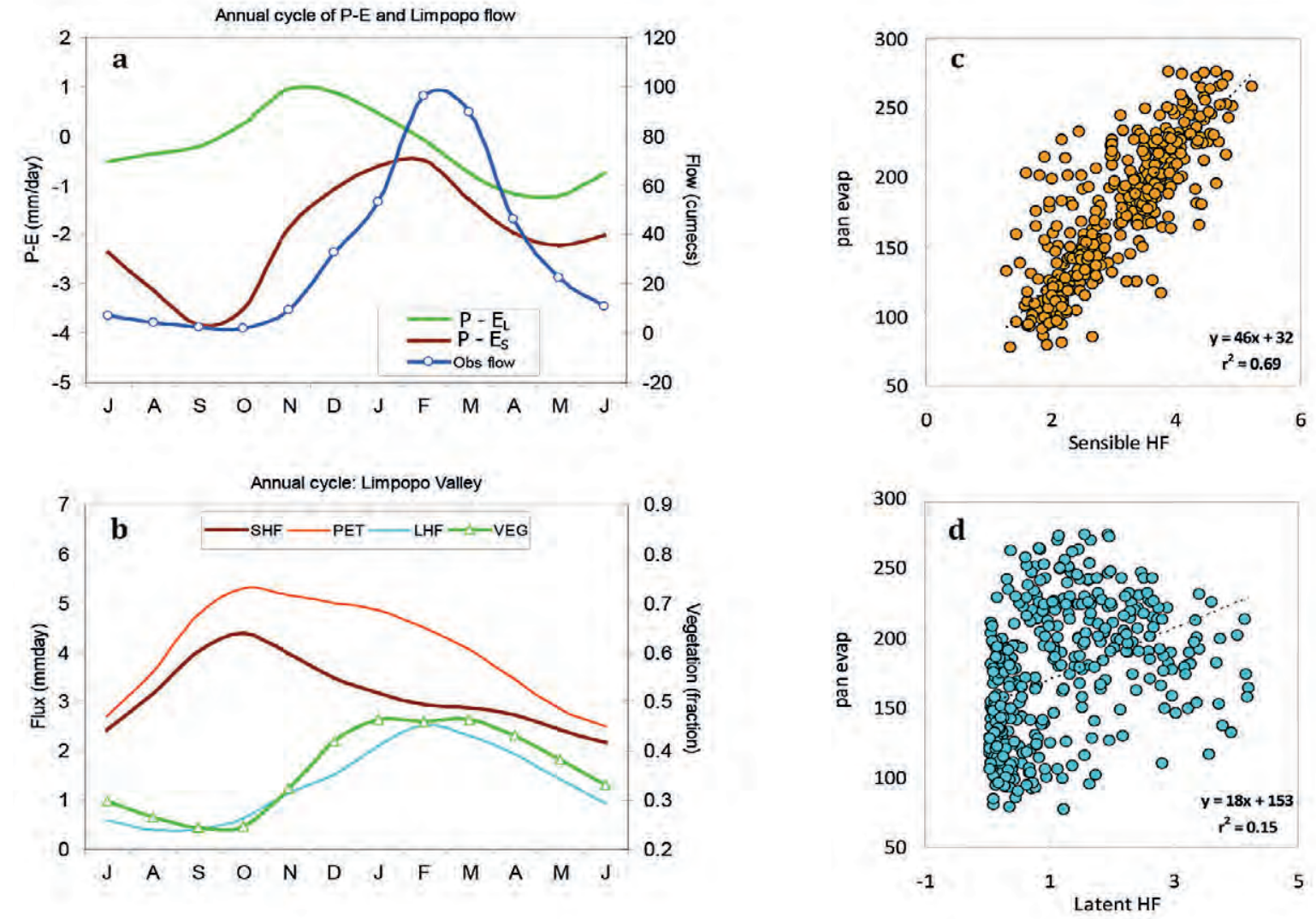

Figure 3

Mean annual cycle of: (a) $P-E_{1}, P-E_{s}$ and river flow, and (b) model sensible and latent heat flux, CRU potential evapo-transpiration and satellite vegetation fraction. Monthly pan evaporation averaged from 3 stations compared with model (c) SHF and (d) $L H F(N=396)$.

\section{Hydrological features}

The smoothed anomalies of rainfall and heat fluxes are given in Fig. 4a. It is apparent that LHF follows rainfall with a 1-2 month lag. Its amplitude is flatter in the 1996 and 2000 wet spells. The sensible heat flux is almost a mirror image of rainfall, being low during wet spells and high in dry spells, one of which (1992) is analysed below. The Dec-Feb SHF in the upper Limpopo Valley is negatively correlated with Jan-Mar satellite vegetation index and ECMWF soil moisture (Fig. 4b,c), both locally and across the Kalahari Desert. The widespread N-S oriented correlation pattern suggests that tropical moisture sources are disconnected from sub-tropical troughs during periods of dessication. 

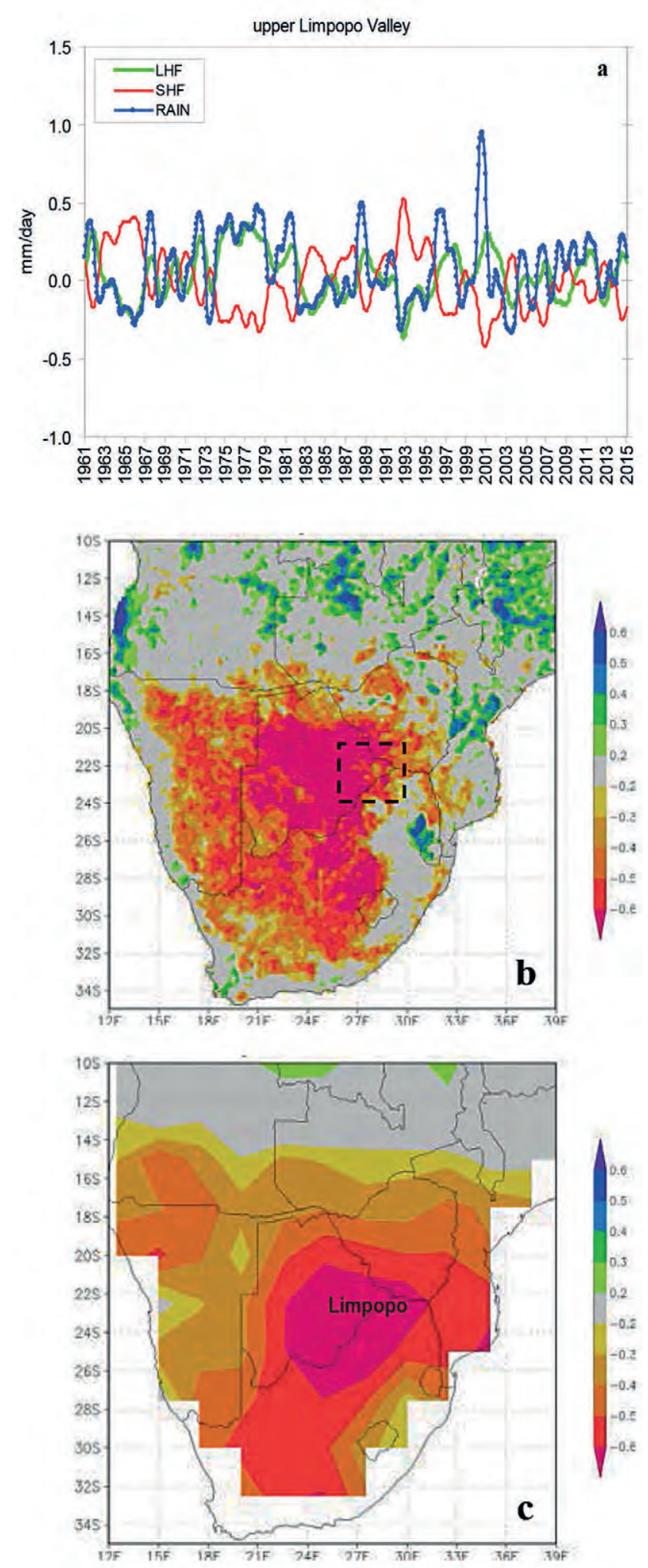

Figure 4

(a) Temporal record of area-averaged filtered precipitation, latent and sensible heat flux anomalies. Correlation of Limpopo Dec-Feb sensible heat flux with Jan-Mar field: (b) satellite vegetation fraction (since 1981) and (c) ECMWF soil moisture, red shaded <-0.2. Dashed box in (b) is the Limpopo area.

\section{A case of drought}

While earlier studies have outlined the origin of South African drought, here the case of highest SHF is studied: Dec 91-Mar 92. The atmospheric circulation anomalies in that summer are illustrated as east-west and north-south slices in Fig. 5a,b. The zonal overturning circulation shows upper level westerly wind anomalies incoming from the Atlantic Ocean with a sinking component from 300 to $800 \mathrm{hPa}$ over and east of the Limpopo Valley, corresponding with relative humidity anomalies $<-15 \%$. A similar pattern was found in the 1983 drought by Taljaard (1989). The meridional circulation anomalies are dominated by upper level divergence south of Africa that provide a northward sinking flow over the Limpopo Valley.

Maps of SHF and $500 \mathrm{hPa}$ vertical motion anomalies averaged Dec 91-Mar 92 illustrate the impact of sinking motions and high surface temperatures (Fig. 5c,d). The normal summer inflow of moist air from the Mozambique Channel was disrupted (Jury and Pathack, 1995). Summer rainfall and LHF collapsed in the Limpopo Valley; consequently South Africa's 1992 maize production value was 1000 times below normal (FAOstat, 2014). This drought persisted until 1996, similar to 1965-1967 and 1982-1987.

\section{A case of flood}

The flood case study focuses on the summer of 2014, when Limpopo River daily flow reached $555 \mathrm{~m}^{3} / \mathrm{s}$ on 16 March (Fig. 6a) following heavy rain from 1-13 March. The spatial pattern of rainfall and low level winds (Fig. 6b) reveals a NW cloud band extending from Angola across Botswana into the Limpopo Valley. Northeast winds fed moist air from the SW Indian Ocean into the cloud band. Airflow back-trajectories on 3-5 March 2014 'funnelled' from Zambia (Fig. 6c), whereas trajectories were from the Mozambique Channel on 6-8 March. The flood was underpinned by a standing wave pattern in the upper level circumpolar westerly winds. High amplitude trough-ridge anomalies (Fig. 6d) caused repeated NW cloud bands.

At regional scale, sea surface temperature anomalies were $-2^{\circ} \mathrm{C}$ in the northern tropics and $+2{ }^{\circ} \mathrm{C}$ in the southern subtropics (Fig. 7a). This 'pushed' the equatorial trough south of its normal position. The vegetation fraction was $>50 \%$ to the northeast of the Limpopo, so incoming air received additional moisture from evapotranspiration. A hovmoller analysis of daily rainfall in Limpopo latitudes (Fig. 7b) shows that numerous easterly waves crossed from Madagascar to southern Africa before the flood $(\mathrm{c} \sim-5.7 \mathrm{~m} / \mathrm{s})$. During and after the flood westerly waves became frequent $(\mathrm{c} \sim+11.3 \mathrm{~m} / \mathrm{s})$. Over the Limpopo there was a wet spell in early February and a dry spell in mid-February. However during the early March flood, a dry spell developed around Madagascar and tropical cyclone formation diminished <en.wikipedia.org/ wiki/2013\%E2\%80\%9314_South-West_Indian_Ocean_ cyclone_season $>$.

\section{Climate influence and trend}

Global climatic influences on Jan-Apr Limpopo River flow are demonstrated in Fig. $8 \mathrm{a}-\mathrm{c}$ by correlation with respect to Dec-Mar surface temperature, air pressure and upper zonal 

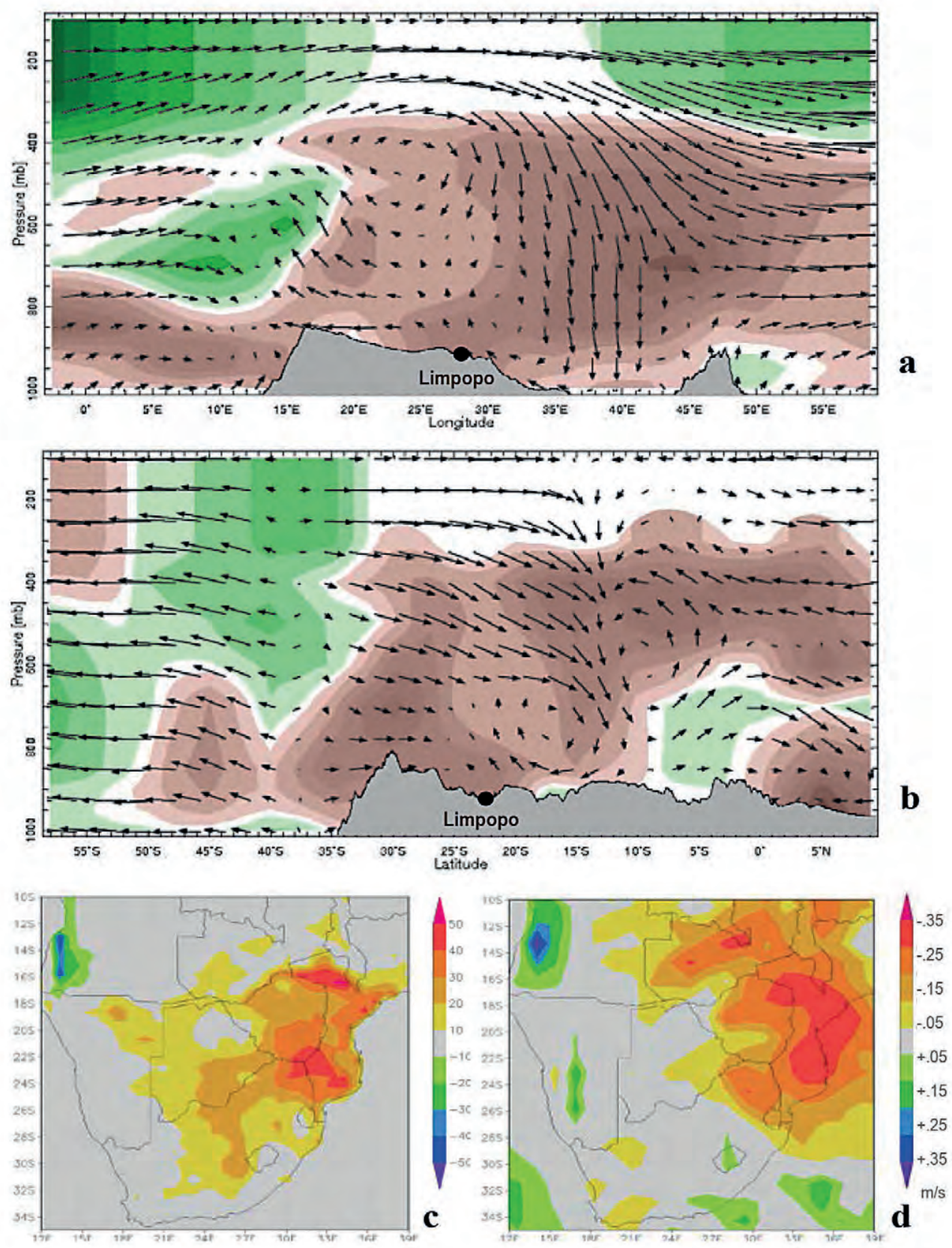

Figure 5

Composite of Limpopo-averaged Dec 91-Mar 92 anomalies: (a) relative humidity and zonal circulation and, (b) relative humidity and meridional circulation. In $(a, b)$ the gauge and topography are given, $R H$ is shaded -15 to $+15 \%$ (brown to green), wind anomalies have maximum $5 \mathrm{~m} / \mathrm{s}$ with vertical motion exaggerated 40 times. (c,d) Dec 1991 to Mar 1992 anomaly maps of ECMWF sensible heat flux (W/m²) and $500 \mathrm{mb}$ vertical motion (m/s).

wind. Increased flow coincides with cool ocean temperatures in the east Pacific consistent with La Niña conditions. Locally there are cool temperatures in the Limpopo region as expected. Air pressure correlations reveal negative values (lower) over the central Atlantic and east Indian Ocean, while positive values (higher) prevail over the east Pacific. In the upper zonal wind pattern, there is a strong negative (easterly) axis stretching across southern Africa that links to the SW Indian Ocean. There is also a banded pattern over the Pacific consistent with La Niña conditions there.

Climatic trends and impacts are considered via Botswana maize yield (FAOstat, 2014) and Limpopo areaaveraged summer maximum temperatures in Fig. 9a. There is a $0.029^{\circ} \mathrm{C} / \mathrm{yr}$ uptrend in temperature ( $13 \%$ of variance) while the maize yield shows a downtrend of $80 \mathrm{~kg} / \mathrm{ha}(30 \%$ of variance). To study whether global warming may induce further dessication, CMIP5 model projections of $P-E_{S}$ in the upper Limpopo Valley are considered (Fig. 9b). Five out of forty CMIP5 models are close to observed $(-1.69$ $\mathrm{mm} /$ day) and their average $P-E_{\mathrm{S}}$ exhibits a downtrend of $-0.0066 \mathrm{~mm} /$ day per year with the rcp6 scenario. Our projections may be compared with similar analyses: (DeWit and Stankiewicz, 2006; Zhu and Ringler, 2010; Jury, 2013; Ngongondo et al., 2013). If soil moisture becomes depleted, the viability of water-intensive crops such as maize is questionable. 

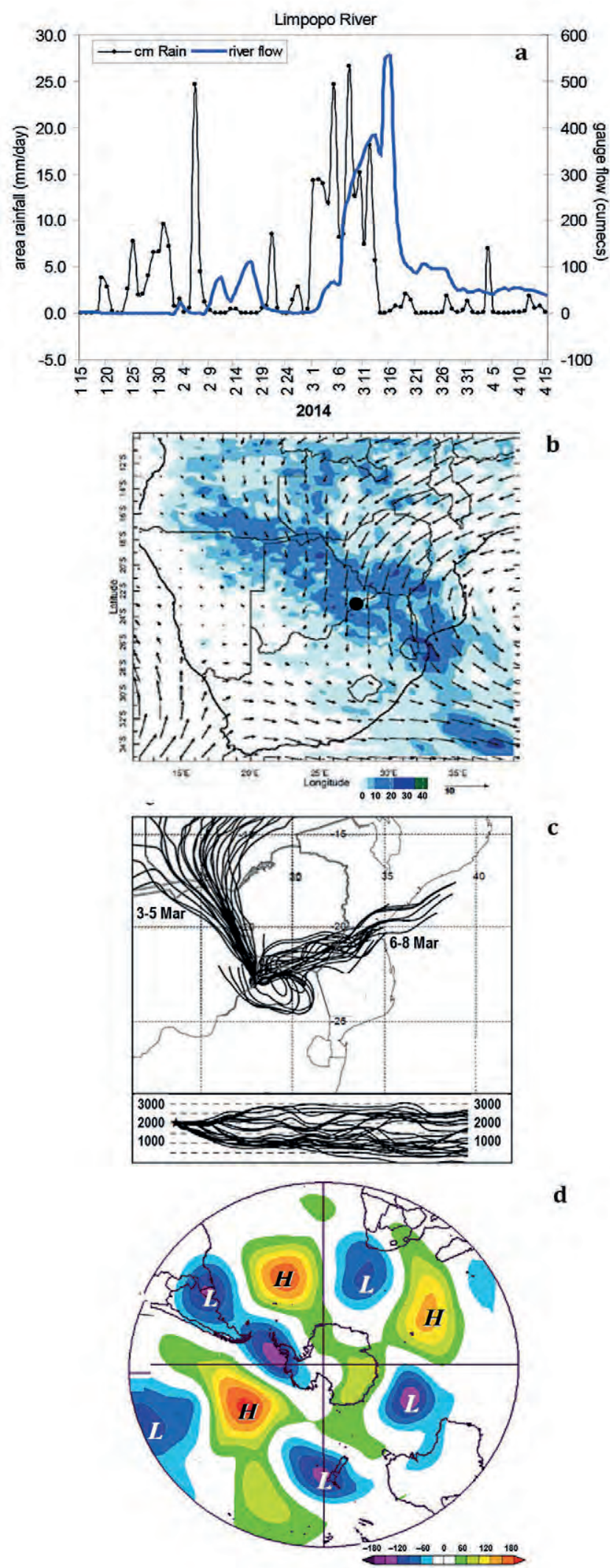

Figure 6

(a) Time series of satellite rainfall and gauge flow during Jan-Apr 2014, (b) 1-13 Mar 2014 rainfall ( $\mathrm{mm} /$ day) and 850-700 hPa winds ( $\mathrm{m} / \mathrm{s} \mathrm{key),}$ (c) Airflow back-trajectories arriving at $2000 \mathrm{~m}$ over the Limpopo gauge 3-5 Mar and 6-8 Mar 2014, (d) 1-13 Mar 2014 southern hemisphere 200 $h$ Pa geopotential height anomalies $(m)$ and icons.

\section{CONCLUDING DISCUSSION}

This study has demonstrated how regional climate influences river flow in the upper Limpopo Valley. Sophisticated highresolution and remotely-sensed datasets were compared with in-situ measurements over a longer record. Rainfall from the GPCC interpolated dataset was contrasted with evaporation losses via SHF. Matsoukas et al. (2011) describe how surface water loss can be characterized by adjusted pan evaporation measurements and Penman-Monteith calculated PET. Here $P-E_{S}$ was seen to lead river flow across the annual cycle (cf. Fig. 3a), producing a deficit $-1.69 \mathrm{~mm} /$ day consistent with soil moisture $\sim 21 \%$. LHF followed rainfall and vegetation; and $P-E_{L}$ gave a neutral water balance inconsistent with deficit conditions.

An analysis of climatic influences on the Limpopo River found that east Pacific La Niña and high pressure favour increased flow, as expected from earlier studies. Here new features were uncovered with regard to low pressure over the central Atlantic and east Indian Ocean, and local upper easterly winds. While dry spells coincide with subsident upper westerly winds (cf. Fig. 5a), floods relate to NW cloud bands (cf. Fig. 6b).

Long-term trends in river flow and the surface water budget were insignificant in the study period 1959-2014; however, CMIP5 model projections exhibited a downtrend in $P-E_{S}$ that suggest additional pressure on water resources. Declining maize yields and warmer temperatures will necessitate conservative planning, innovative engineering and recycling efforts (UNDP, 2007) to meet the needs of a growing population. Further research is recommended to quantify run-off on the northern flank of the Limpopo Valley (Botswana, Zimbabwe), supported by remote sensing observations.

\section{ACKNOWLEDGEMENTS}

The author thanks South Africa's Department of Water and Sanitation for hydrological data distributed by Internet. Satellite and model interpolated data were analysed from the KNMI Climate Explorer, IRI Climate Library, NASA Giovanni and NOAA READY-ARL websites. SAPSE support from the South African Department of Higher Education and Training is acknowledged.

\section{REFERENCES}

DEE DP, UPPALA SM, SIMMONS AJ, BERRISFORD P, POLI P, KOBAYASHI S, ANDRAE U, BALMASEDA MA, BALSAMO G, BAUER P and co-authors (2011) The ERA-Interim reanalysis: configuration and performance of the data assimilation system. Q. J. R.l Meteorol. Soc. 137 553-597. http://dx.doi.org/10.1002/qj.828

DeWIT M and STANKIEWICZ J (2006) Changes in surface water supply across Africa with predicted climate change. Science 301 1917-1921. http://dx.doi.org/10.1126/science.1119929

EKBLOM A, LINDESAY G, RISBERG J and HOLMGREN K (2012) Rainfall variability and vegetation dynamics of the lower Limpopo Valley Southern Africa, 500 AD to present. Palaeogeogr. Palaeoclimatol. Palaeoecol. 363 69-78. http://dx.doi.org/10.1016/j. palaeo.2012.08.015

FAOstat (2014) Food and Agricultural Organization statistical database. http://faostat.fao.org/ (Accessed 20 August 2015).

GLAD PA (2010) Meteorological and hydrological conditions leading to severe regional drought in Malawi. MSc thesis, Dept Geoscience, University of Oslo. 129 pp.

HARGREAVES GH and SAMANI ZA (1982) Estimating potential evaptranspiration. J. Irrig. Drain. Div ASCE 108 225-230.

HARRIS I, JONES PD, OSBORN TJ and LISTER DH (2013) Updated 

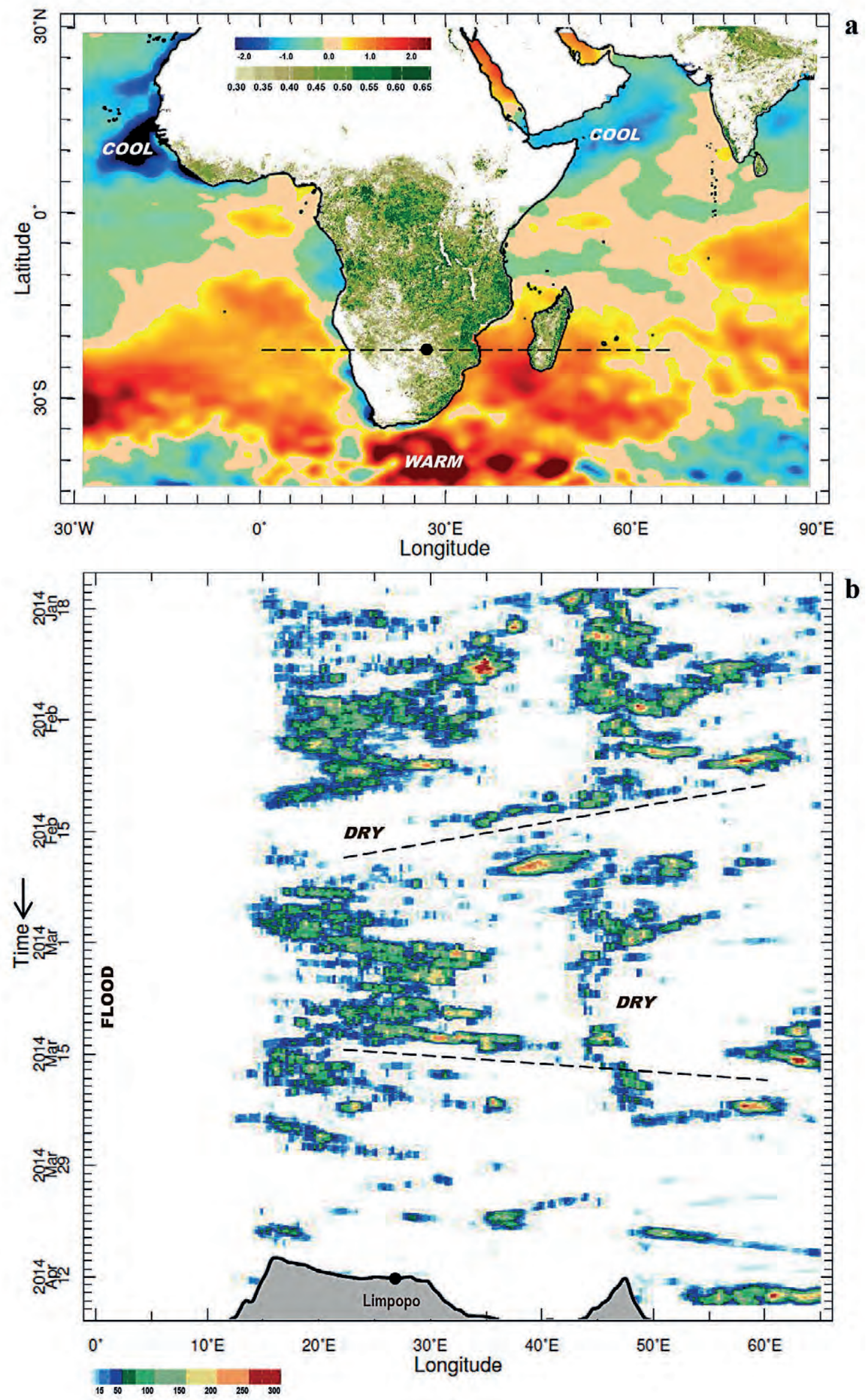

Figure 7

(a) Satellite vegetation fraction (green scale) and sea surface temperature anomalies $\left({ }^{\circ} \mathrm{C}\right.$ ) 1-13 Mar 2014. Line indicates latitude of analysis below. (b) Hovmoller analysis of satellite daily rainfall (mm/day) averaged over Limpopo latitude 15 Jan-15 Apr 2014. Dashed lines identify zonal waves, labels highlight dry spells, schematic topography given lower. 

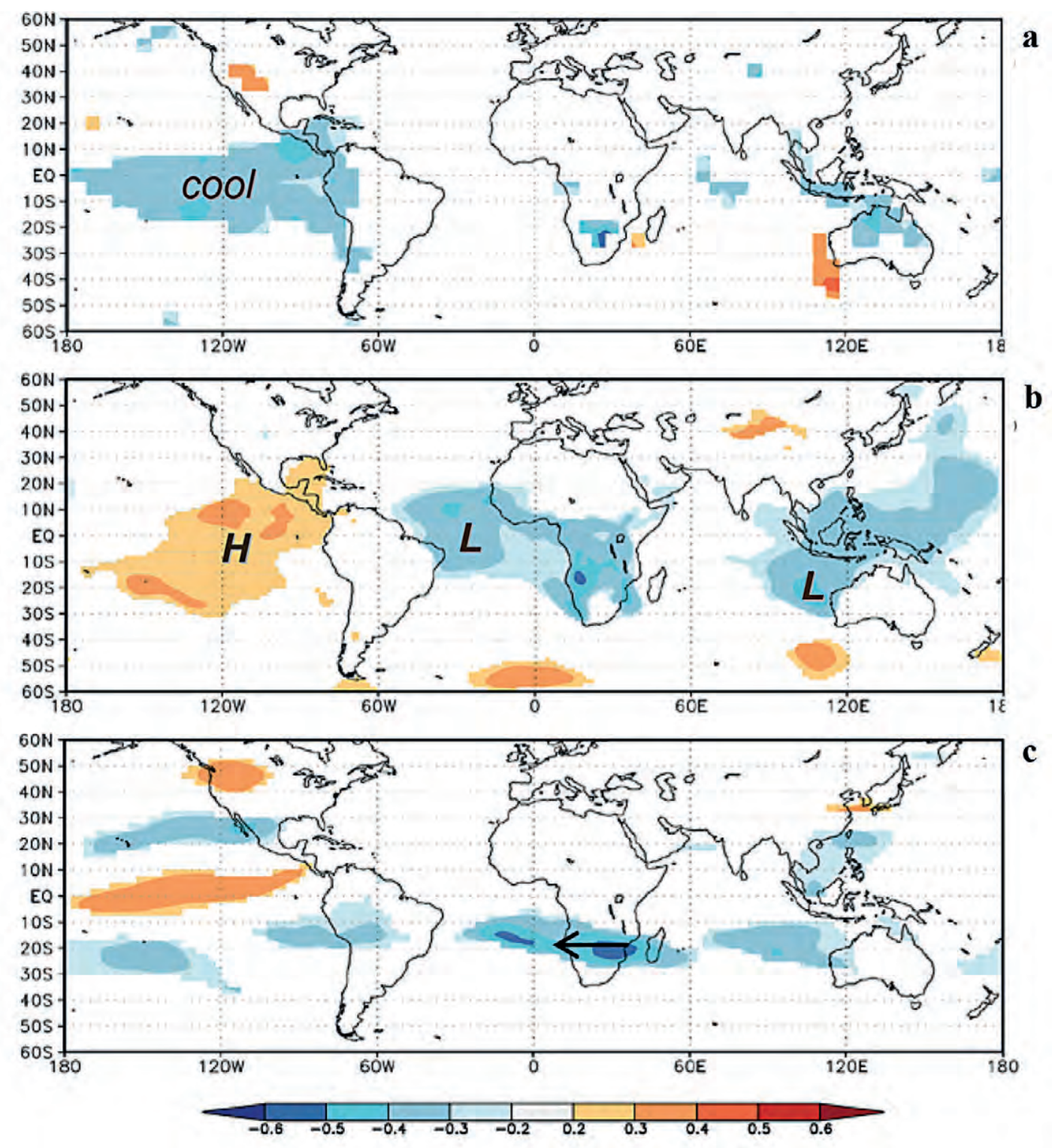

Figure 8

Correlation maps of Jan-Apr Limpopo River flow with respect to Dec-Mar fields: (a) surface temperature, (b) sea level pressure, (c) $200 \mathrm{hPa}$ zonal wind. Correlation values $<90 \%$ confidence are masked.
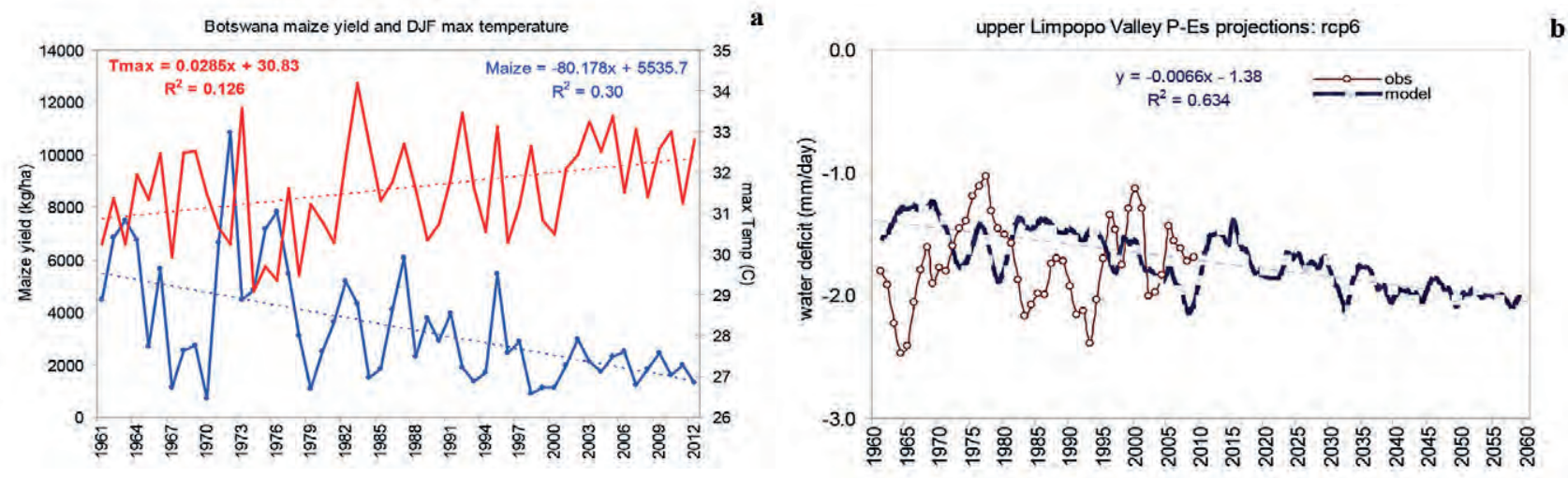

Figure 9

(a) Botswana maize yield and summer maximum temperatures (red) and their respective linear trends. (b) Limpopo Valley observed and CMIP5 projected $P-E_{s}$ for 'valid' models and the linear trend. 
high-resolution grids of monthly climatic observations Int. J. Climatol. http://dx.doi.org/10.1002/joc.3711

HUETE A, DIDAN K, MIURA T, RODRIGUEZ EP, GAO X and FERRIERA LG (2002) Overview of the radiometric and biophysical performance of the MODIS vegetation indices. Remote Sens. Environ. 83 195-213. http://dx.doi.org/10.1016/ S0034-4257(02)00096-2

JOYCE RJ, JANOWIAK JE, ARKIN PA and XIE PP (2004) CMORPH: A method that produces global precipitation estimates from passive microwave and infrared data at high spatial and temporal resolution. J. Hydrometeorol. 5 487-503. http://dx.doi. org/10.1175/1525-7541(2004)005<0487:CAMTPG >2.0.CO;2

JURY MR and PATHACK BMR (1995) Climatic patterns associated with the 1992 drought over southern Africa, observations and GCM results. J. Afr. Meteorol. Soc. 2 1-7.

JURY MR (2012) An inter-comparison of model simulated east-west climate gradients over South Africa. Water SA 38 1-11. http:// dx.doi.org/10.4314/wsa.v38i4.1

JURY MR (2013) Climate trends in southern Africa S. Afr. J. Sci. 109 53-63.

KUMAMBALA PG and ERVINE A (2010) Water balance model of Lake Malawi and its sensitivity to climate change. Hydrol. J. 4 152-162.

LBPTC [LIMPOPO BASIN PERMANENT TECHNICAL COMMITTEE] (2010) Joint Limpopo River Basin study, Scoping report. LBPTC, Maputo. 91 pp. URL: http://www.limcom.org/_system/writable/DMSStorage/1031en/LIMCOM2010_ScopingStudy_ Eng.pdf (Accessed 15 September 2015).

MATSOUKAS C, BENAS N, HATZIANASTOUSIOU N, PAVLAKIS KG, KANAKIDOU M and VARDAVAS I (2011) Potential evaporation trends over land between 1983-2008: driven by radiative fluxes or vapour-pressure deficit? Atmos. Chem. Phys. 11 7601-7616. http://dx.doi.org/10.5194/acp-11-7601-2011

NGONGONDO C, LI L, GONG L, XU C-Y and ALEMAW BF (2013) Flood frequency under changing climate in the upper Kafue River basin, southern Africa: a large scale hydrological model application. Stoch. Environ. Res. Risk. Assess. 27 1883-1898. http://dx.doi. org/10.1007/s00477-013-0724-Z

POTTER C, ZHANG P, KLOSTER S, GENOVESE V, SHEKHAR S and KUMAR V (2004) Understanding controls on historical river discharge in the world's largest drainage basins. Earth Interactions 8 1-21. http://dx.doi.org/10.1175/1087-3562(2004)008<0001:UCOH $\mathrm{RD}>2.0 . \mathrm{CO} ; 2$
RIENECKER MM, SUAREZ MJ, GELARO R, TODLING R, BACMEISTER J, LIU E, BOSILOVICH MG, SCHUBERT SD, TAKACS L, KIM G-K and co-authors (2011) MERRA: NASA's Modern-Era Retrospective Analysis for Research and Applications. J. Clim. 24 3624-3648. http://dx.doi.org/10.1175/ JCLI-D-11-00015.1

RODELL M M, MITCHELL K, WALKER PJ, MENG CJ, GOTTSCHALCK J, LOHMANN D, HOUSER PR, JAMBOR U, ARSENAULT K, COSGROVE B and co-authors (2004) The Global Land Data Assimilation System. Bull. Am. Meteorol. Soc. 85 381-394. http://dx.doi.org/10.1175/BAMS-85-3-381

SCHNEIDER U, BECKER A, FINGER P, MEYER-CHRISTOFFER A, ZIESE M and RUDOLF B (2013) GPCC's new land surface precipitation climatology based on quality-controlled in-situ data and its role in quantifying the global water cycle. Theor. Appl. Climatol. http://dx.doi.org/10.1007/s00704-013-0860-x

TADROSS MA, HEWITSON BC and USMAN MT (2005) The interannual variability of the onset of the maize growing season over South Africa and Zimbabwe. J. Clim. 18 3356-3372. http://dx.doi. org/10.1175/JCLI3423.1

TALJA ARD JJ (1989) Climate and circulation anomalies in the South African region during the dry summer of 1982/3. SA Weather Bureau Tech Paper 21. South African Weather Bureau, Pretoria. 45 pp.

TAYLOR KE, STOUFFER RJ and MEEHL GA (2012) An overview of CMIP5 and the experiment design. Bull. Am. Meteorol. Soc. 93 485-498. http://dx.doi.org/10.1175/BAMS-D-11-00094.1

TYSON PD, LEE-THORP J, HOLMGREN K and THACKEREY JF (2002) Changing gradients of climate in southern Africa during the past millennium: implications for population movements. Clim. Change 52 129-135. http://dx.doi.org/10.1023/A:1013099104598

UNDP (UNITED NATIONS DEVELOPMENT PROGRAMME) (2007) Limpopo Basin plan for reducing vulnerability to floods and drought. UNDP, Geneva. 25 pp.

VENTER FJ, SCHOLES RJ and ECKHARDT HC (2003) The abiotic template and its associated vegetation pattern. In: Du Toit JT, Rogers KH and Biggs HC (eds) The Kruger Experience: Ecology and Management of Savanna Heterogeneity. Island Press, Washington. 83-129.

ZHU T and RINGLER C (2010) Climate change implications for water resources in the Limpopo River Basin. IFPRI Report 00961. IFPRI, Washington, DC. 16 pp 